\title{
Evaluation of cement-bonded particleboards produced from mixed sawmill residues
}

\author{
S. O. Amiandamhen ${ }^{1,2}$ (D) C. U. Agwu' ${ }^{2}$ P. N. Ezenwaegbu ${ }^{2}$
}

Received: 28 May 2019/Accepted: 15 April 2021/Published online: 28 April 2021

(C) The Author(s) 2021

\begin{abstract}
This study evaluates the application feasibility and properties of cement-bonded particleboards produced from mixed tropical hardwood species. Wood residues from a typical sawmill were collected, dried and used in the manufacturing of the cement composites. The wood residues used were from Ceiba pentandra and Gmelina arborea timber species. The residues were mixed in seven ratios in the production of the composite samples. Two control experimental samples containing unmixed residues of each species were also produced. The test carried out on the boards were flexural strength, water uptake properties and wet and dry screw withdrawal resistance. The effect of the wood mix ratio on the board properties was evaluated. The result showed that all properties except the screw withdrawal resistance were significantly influenced by the mix ratios $(p<0.05)$. The wet and dry screw withdrawal resistance ranged from 1170 to $1770 \mathrm{~N}$ and 1360 to $1830 \mathrm{~N}$, respectively. The optimum wood mix ratio for enhancing mechanical performance of the boards was 1:4 of $C$. pentandra/G. arborea wood residues. Based on the result of this study, the particleboards produced can be used as wood composite ceiling tiles in building applications.
\end{abstract}

Keywords Cement-bonded particleboard · Flexural strength $\cdot$ Sawmill wood residues $\cdot$ Screw withdrawal resistance $\cdot$ Wood mix

S. O. Amiandamhen

stephen.amiandamhen@1nu.se

1 Department of Forestry and Wood Technology, Linnaeus University, Växjö, Sweden

2 Department of Forest Resources and Wildlife Management, University of Benin, Benin City, Nigeria

\section{Introduction}

Wood processing mills generate millions of tonnes of residues annually. Some of these residues include sawdust, planer shavings and bark, which are often incinerated to generate heat energy in integrated sawmills. In some cases, such residues are collected at municipal plants and incinerated to generate heat for district heating and electricity (Alm and Karlsson 2016). The beneficial use of sawmill residues in green heating systems is only applicable in developed countries, where such processes complement and have almost replaced the fossil-based heating grid. However, in developing countries, much of these residues are treated as waste having no commercial value. Many sawmills do not have the facilities to incinerate residues and usually carry out open burning practices (Fabunmi et al. 2012; Effah et al. 2015). This method is of serious environmental concern with the release of volatile compounds and particulate matter in the atmosphere. Landfilling as an option is also not generally practiced because it increases the total cost of processing, coupled with the shortage of available landfills. It therefore becomes imperative to find alternative ways by which these residues can be utilized within the scope and capability of a developing economy. In Africa, sawmill residues are inevitable but a significant volume may be reduced by careful process optimization. However, these residues are being utilized in other areas of applications including wood composite manufacturing, wood pelletization, animal bedding, etc. One major limitation in the use of this material is that it sometimes contains residues from several tree species that are converted within a period. Some of these residues may not be suitable for the intended application, and sorting may be a difficult option to implement when different timber species are converted together. This 
study therefore investigates the use of such mixed residues in manufacturing cement-bonded ceiling tiles.

Cement-bonded wood particleboard has been the subject of many researches for many decades. Different wood species, including lignocellulosic fiber materials, have been used to produce composite boards bonded with Portland cement (Savastano et al. 2000; Semple et al. 2002; Fan et al. 2012; Ardanuy et al. 2015). In addition, mixed-wood and non-wood species have been used to produce cement and lime-bonded boards (Badejo 1988; Aigbomian and Fan 2013; Garcez et al. 2016). This study seeks to address the potential of residues of some tropical hardwood species as raw materials for manufacturing cement-bonded ceiling tiles. The species of interest include Ceiba pentandra and Gmelina arborea which are predominant in the area of study. The use of these mixed-wood species in cementbonded composites has not been previously reported in the literature. However, cement composites with $G$. arborea wood residues have been studied (Aladenola et al. 2008; Amiandamhen and Izekor 2013; Owoyemi and Ogunrinde 2016). The manufacturing of cement-bonded particleboard is faced with some disadvantages, one of which is the inherent incompatibility between some wood species and Portland cement (Na et al. 2014; Hachmi et al. 2017). As a result, inhibiting species are sometimes treated or additives are used to reduce the setting time of cement (Karade et al. 2003; Na et al. 2014). In this study, the wood species were treated with hot water and calcium chloride $\left(\mathrm{CaCl}_{2}\right)$ was used as an additive. This was necessary based on the results from previous study using G. arborea sawdust (Amiandamhen and Izekor 2013).

The properties of cement-bonded particleboards depend on several parameters including the nature of the biomass material, the biomass blends and the ratio of the cementbiomass mix (Sotannde et al. 2012; Castro et al. 2018). Similarly, several studies have investigated the properties of cement-bonded particleboards produced from mixed biomass species; however, there are very few studies on the performance of controlled mixing of wood species in cement composites. In one study, Garcez et al. (2016) blended Eucalyptus grandis and Pinus ellioti sawdust between 0 and $100 \%$ by mass and found intermediate to lower values of compressive strength and intermediate to higher values of dynamic modulus of elasticity. Woodcement boards with $100 \%$ of $E$. grandis sawdust had higher values of compressive strength compared to boards with $P$. ellioti sawdust (Garcez et al. 2016). In a blend of hardwoods and softwoods for wood-crete production, Aigbomian and Fan (2013) found lower composite properties compared to unblended composites, which could be a result of an adverse effect of mixing, such as bridging between the particles. Thus, there is a literature gap on the properties of blended hardwood species. Therefore, the objective of this study is to evaluate the properties of cement-bonded particleboard made from mixing two tropical hardwood species. The aim of the study is to demonstrate the feasibility of manufacturing wood-cement ceiling boards from mixed-wood residues obtained from a typical sawmill in Benin City, Nigeria.

\section{Experimental}

The wood residues used were Ceiba pentandra (L.) Gaertn. and Gmelina arborea Roxb. The residues were collected from a local sawmill just after primary conversion of the $\operatorname{logs}$. The wet residues were air-dried to a moisture content of $18 \%$. The wood residues were hammer-milled and sieved through a 1-mm mesh. The particles were soaked in hot water maintained at a constant temperature of $100{ }^{\circ} \mathrm{C}$ in a water bath for $1 \mathrm{~h}$. This was necessary to remove any water-soluble sugars and hemicelluloses which tend to inhibit cement hydration. The leachate was drained and the wood particles were air-dried for $24 \mathrm{~h}$. Thereafter, the particles were conditioned at $20{ }^{\circ} \mathrm{C}$ and $65 \%$ relative humidity (RH) for $96 \mathrm{~h}$ to an equilibrium moisture content of $12 \%$.

\section{Sample preparation and testing}

The target board density was $1.2 \mathrm{~g} / \mathrm{cm}^{3}$ for a cement/wood ratio of 2:1. The actual board size was $350 \times 350 \times 6 \mathrm{~mm}$. Therefore, the amount of cement and wood particles in each board was 588 and $294 \mathrm{~g}$, respectively. A pre-calculated amount of water, based on the relationship used in previous study (Amiandamhen et al. 2016), was added to the mixture. A measured quantity of $\mathrm{CaCl}_{2}(3 \% \mathrm{w} / \mathrm{w}$ of the cement) was dissolved in the water to accelerate the hydration process of the cement.

The wood particles were mixed together according to Table 1.

The wood particles, cement and water were mixed thoroughly in a planetary style mixer for about $10 \mathrm{~min}$. The mixture was transferred quantitatively into a wooden mold of known dimensions. The preformed mat was covered with metal plates, and a metal bar was placed at the edge of the bottom plate to set the thickness of the board. The plate was cold-pressed at $1.23 \mathrm{MPa}$ for $24 \mathrm{~h}$. The same procedure was repeated for all the samples (A-I). Each sample was replicated four times. Thereafter, the plates were removed and the boards were air-cured for 28 days prior to cutting and testing.

The edges of the boards were trimmed to avoid edge effects. The boards were cut into test sample sizes according to ASTM D1037 (2012) and conditioned at $20{ }^{\circ} \mathrm{C}$ and $65 \% \mathrm{RH}$ for $96 \mathrm{~h}$ before testing. The tests 
Table 1 Wood mix ratios

\begin{tabular}{llll}
\hline Samples & Wood mix ratio & C. pentandra $(\%)$ & G. arborea $(\%)$ \\
\hline A & $1: 1$ & 50 & 50 \\
B & $1.5: 1$ & 60 & 40 \\
C & $1: 1.5$ & 40 & 60 \\
D & Control & 0 & 100 \\
E & Control & 100 & 0 \\
F & $2.3: 1$ & 70 & 30 \\
G & $1: 2.3$ & 30 & 70 \\
H & $1: 4$ & 20 & 80 \\
I & $4: 1$ & 80 & 20 \\
\hline
\end{tabular}

evaluated were modulus of rupture (MOR), apparent modulus of elasticity (MOE), wet and dry screw withdrawal resistance (WSW/DSW), water absorption (WA) and thickness swelling (TS). These tests were considered due to the proposed ceiling application of the products and were performed according to ASTM D1037 (2012). Preliminary investigations using $C$. pentandra sawdust in a cement/wood ratio of 2:1 yielded poor screw withdrawal resistance and high water absorption. It is the aim of this study to evaluate these properties and ascertain the potential of the combined residues for manufacturing marketable ceiling boards.

\section{Experimental design and analysis}

The experiment was laid out as a completely randomized design with nine treatments (wood mix ratios) and four replicates. Analysis of variance (ANOVA) was conducted to determine the effect of the production variables (mix ratios) on the properties evaluated. Duncan's new multiple range test (DNMRT) was used in the separation of means where significant differences occurred.

\section{Results and discussion}

\section{Effect of wood mix ratios on MOE and MOR}

Figure 1 shows the effect of the wood mix ratios on the MOE of the cement boards. Sample H with a mix ratio of 1:4 (C. pentandra/G. arborea) had the highest mean MOE of $2.73 \mathrm{GPa}$. Moderate values were also observed for samples F, A and E with mix ratios of 2.3:1, 1:1 and unmixed $C$. pentandra boards, respectively. There was no relationship between the mixing ratios and MOE. The average MOE value obtained in this study is in the range reported by Tittelein et al. (2012) of a low-density wood- cement particleboard using a cement/wood ratio of 2:1. Although stiffness characteristic is a function of the cement-wood ratio (Frybort et al. 2008), the presence of different wood species may cause considerable variation in mechanical properties (Garcez et al. 2016). From the result, sample $G$ with a mix ratio of 1:2.3 (C. pentandra/G. arborea) had the lowest mean MOE.

The MOR of the samples is presented in Fig. 2. The mean MOR values ranged from 0.43 to $4.13 \mathrm{MPa}$. Samples $\mathrm{E}$ and $\mathrm{H}$ have higher MOR values of 4.13 and $4.08 \mathrm{MPa}$, respectively. This indicates that the wood mix ratio in sample $\mathrm{H}(1: 4, C$. pentandra/G. arborea) is optimum mix for enhancing the flexural property of the wood-cement composites. Sample E with $100 \%$ C. pentandra also proved to yield good bending property. The pattern of variation among the other samples shows that there is no linear relationship between the MOR and the wood mix ratios. Similar values in MOR were also observed by several authors, although the studies reported were from single wood species (Sotannde et al. 2012; Tittelein et al. 2012; Amiandamhen and Izekor 2013).

\section{Effect of wood mix ratios on WA and TS}

The results of the 24-h submersion of the samples in water for WA and TS are presented in Figs. 3 and 4, respectively. The WA test showed that boards made from unmixed $G$. arborea had the lowest mean value of $18.63 \%$, while boards produced from unmixed $C$. pentandra had the highest mean value of $53.64 \%$. The mean WA values for the other mixing ratios, with the exception of $1: 1$ ( $C$. pentandra/G. arborea), were relatively high. This indicates that the samples absorb too much water during submersion, probably due to an adverse effect of mixing as observed by Aigbomian and Fan (2013). From the observation, it could be explained that inadequate inter-particle mixing results in a porous structure in the matrix, which inevitably leads to high water absorption. On the contrary, unmixed $G$. arborea sawdust forms a relatively compacted product with

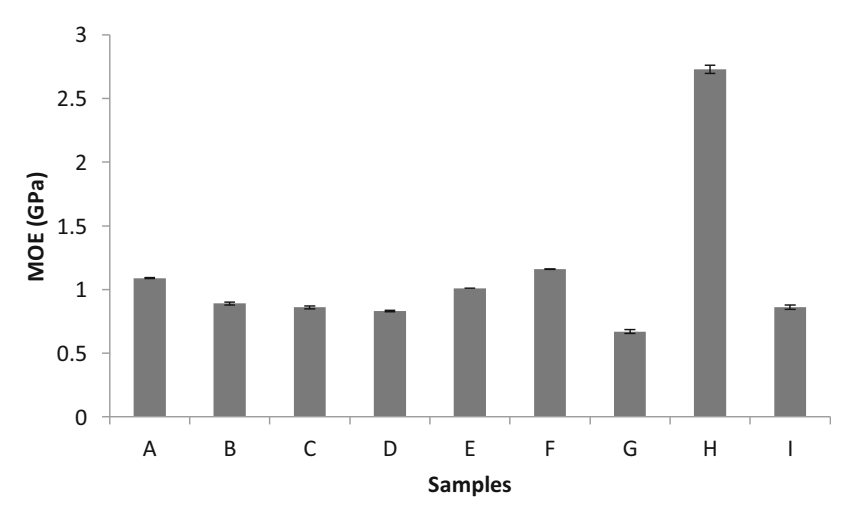

Fig. 1 Effect of mix ratio on MOE 


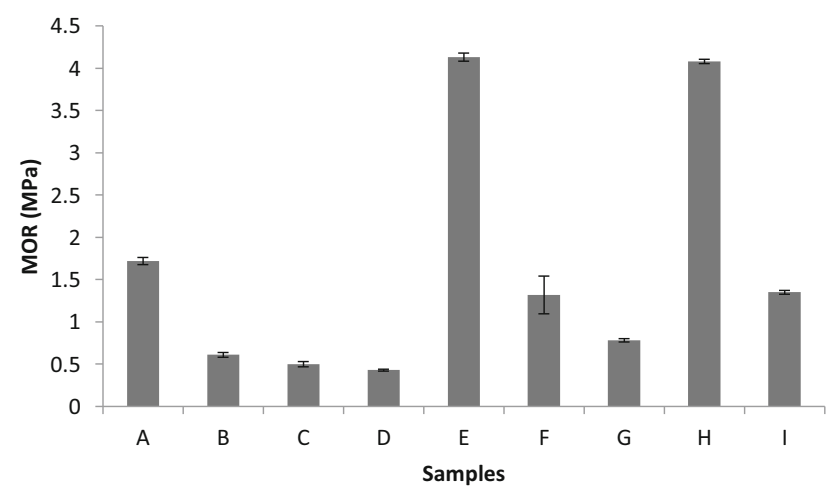

Fig. 2 Effect of mix ratio on MOR

cement, and the product is moderately resistant to moisture (Amiandamhen et al. 2016). The TS of the particleboards ranged from 6.43 to $14.32 \%$. Sample F had the least TS, while sample $\mathrm{G}$ had the highest TS.

\section{Effect of wood mix ratios on WSW/DSW}

Figure 5 shows the WSW and DSW perpendicular to the plane of the tested samples. DSW was carried out on samples at $12 \%$ moisture content, while WSW was carried out at a MC of $60 \%$. Static withdrawal was performed at a rate of $6.6 \mathrm{~mm} / \mathrm{min}$ according to the procedure of Rammer and Zelinka (2004). Sample C with a wood mix ratio of 1:1.5 (C. pentandra/G. arborea) had the lowest mean value of 1360 and $1170 \mathrm{~N}$, while sample I with a ratio of 4:1 (C. pentandra/G. arborea) had the highest mean value of 1830 and $1770 \mathrm{~N}$ for DSW and WSW, respectively. Although SW depends on the particleboard density among several factors (Miljković et al. 2007), it was observed that the values vary slightly irrespective of the sample density. Okino et al. (2004) also reported that the SW perpendicular to the plane of particleboard was between 1500 and $2020 \mathrm{~N}$. These values are higher than the previous values obtained for nail withdrawal resistance of the same type of panels. Other authors also found screw withdrawal

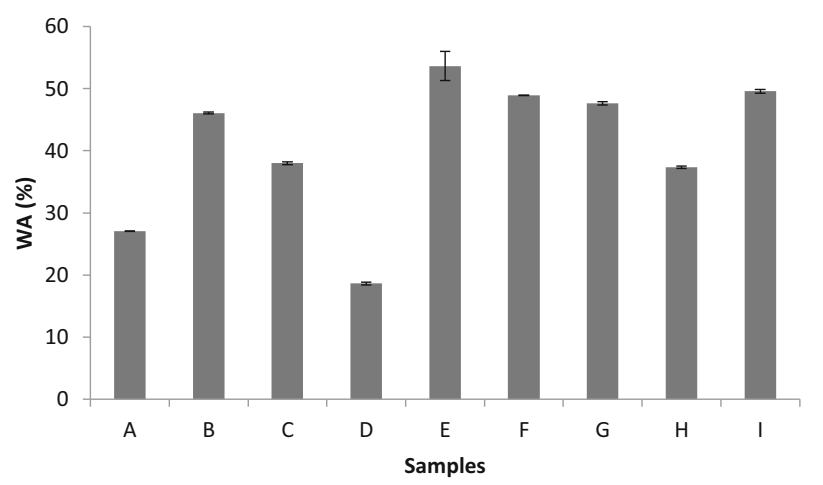

Fig. 3 Effect of mix ratio on WA

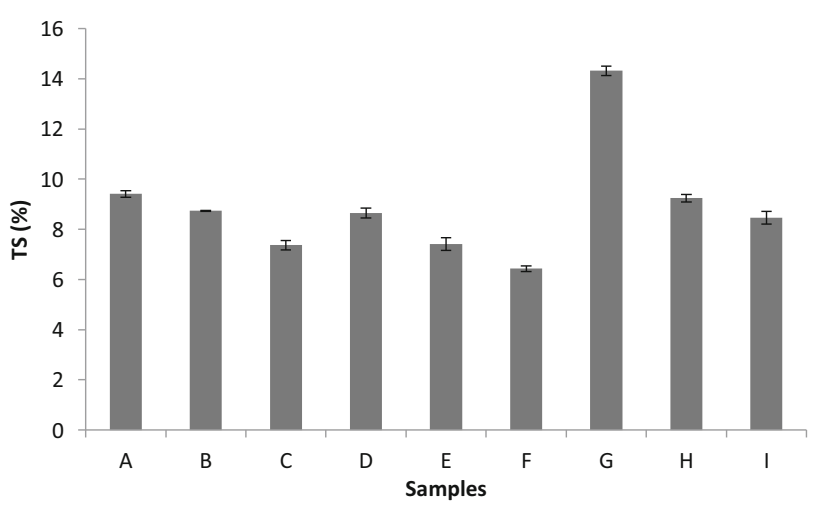

Fig. 4 Effect of mix ratio on TS

resistance to be higher than nail withdrawal resistance. This difference is due to the surface friction, which holds the fastener in a structural panel. The greater the frictional surface, the higher the withdrawal strength (Rammer and Zelinka 2004).

\section{Data analysis and mean comparisons}

The result of the ANOVA is presented in Table 2. It was observed that the wood mix ratios have a significant effect on the properties evaluated on the particleboard $(p<0.05)$, except for the wet and dry screw withdrawal resistance. Table 3 shows the multiple mean comparisons on the board properties.

\section{Conclusions}

The increasing interest by many countries in cement-bonded wood products is likely due to the durability of the product, markets and design flexibility. With affordable technology and materials, this product provides the opportunity to increase the economic potential of developing countries. Wood residues will continue to be a significant material for manufacturing cement-bonded products in developing countries, because of the high volume of the residues generated in sawmills. The utilization of these residues will not only reduce the negative environment effects associated with open burning, but will also help to promote a circular bioeconomy.

From a typical sawmill that generates different wood residues, it is almost impossible to sort these residues according to species. This study was conducted to provide a technical assessment of the feasibility of producing cement-bonded particleboards produced from mixed residues and evaluation of the board properties for ceiling applications. The study revealed that the physical properties of the particleboards produced met the minimum 
Fig. 5 Effect of mix ratios on WSW/DSW

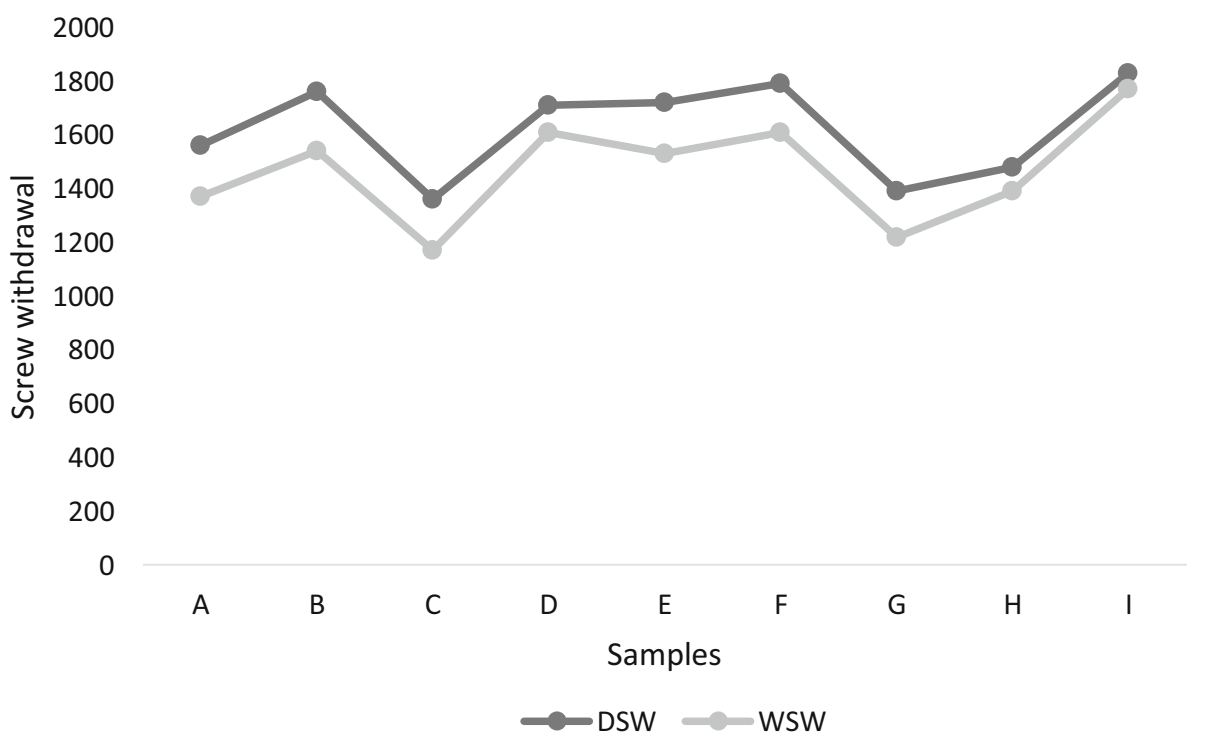

Table 2 ANOVA of the board properties

\begin{tabular}{|c|c|c|c|c|c|}
\hline & \multicolumn{3}{|c|}{ Mechanical properties } & \multicolumn{2}{|c|}{ Physical properties } \\
\hline & MOR & MOE & SW & WA & TS \\
\hline$F$ value & 220.22 & 1805.95 & 370.58 & 205.15 & 159.29 \\
\hline$p$ & $0.00017 *$ & $0.00012 *$ & 0.068 & $0.00048 *$ & $0.00011^{\prime}$ \\
\hline
\end{tabular}

*Represents significant values at $p<0.05$
Table 3 Multiple mean comparisons of the board properties

\begin{tabular}{lllll}
\hline Samples & MOE $(\mathrm{GPa})$ & MOR $(\mathrm{MPa})$ & WA $(\%)$ & TS $(\%)$ \\
\hline A & $1.09^{\mathrm{e}}$ & $1.72^{\mathrm{e}}$ & $27.03^{\mathrm{b}}$ & $9.41^{\mathrm{e}}$ \\
B & $0.89^{\mathrm{bc}}$ & $0.61^{\mathrm{ab}}$ & $46.05^{\mathrm{d}}$ & $8.74^{\mathrm{cd}}$ \\
C & $0.86^{\mathrm{b}}$ & $0.5^{\mathrm{a}}$ & $38^{\mathrm{c}}$ & $7.37^{\mathrm{b}}$ \\
D & $0.83^{\mathrm{b}}$ & $0.43^{\mathrm{a}}$ & $18.63^{\mathrm{a}}$ & $8.64^{\mathrm{c}}$ \\
E & $1.01^{\mathrm{d}}$ & $4.13^{\mathrm{f}}$ & $53.64^{\mathrm{f}}$ & $7.41^{\mathrm{b}}$ \\
F & $1.16^{\mathrm{f}}$ & $1.32^{\mathrm{d}}$ & $48.92^{\mathrm{e}}$ & $6.43^{\mathrm{a}}$ \\
G & $0.67^{\mathrm{a}}$ & $0.78^{\mathrm{bc}}$ & $47.62 \mathrm{~d}^{\mathrm{e}}$ & $14.32^{\mathrm{f}}$ \\
H & $2.73^{\mathrm{f}}$ & $4.08^{\mathrm{f}}$ & $37.32^{\mathrm{c}}$ & $9.24 \mathrm{~d}^{\mathrm{e}}$ \\
I & $0.86^{\mathrm{b}}$ & $1.35^{\mathrm{d}}$ & $49.57^{\mathrm{e}}$ & $8.46^{\mathrm{c}}$ \\
\hline
\end{tabular}

Means in the same column with same or similar letter are not significantly different $(p<0.05)$

requirements for cement-bonded particleboards according to BS EN 634-2 (2007), for use in humid and dry environments. As a result, the products can be used for the proposed application as ceiling tiles for building constructions. For manufacturing structural panels using these wood residues, increasing the cement content is recommended for durability purposes.
Funding Open access funding provided by Linnaeus University.

Open Access This article is licensed under a Creative Commons Attribution 4.0 International License, which permits use, sharing, adaptation, distribution and reproduction in any medium or format, as long as you give appropriate credit to the original author(s) and the source, provide a link to the Creative Commons licence, and indicate if changes were made. The images or other third party material in this article are included in the article's Creative Commons licence, unless indicated otherwise in a credit line to the material. If material is not included in the article's Creative Commons licence and your intended use is not permitted by statutory regulation or exceeds the permitted use, you will need to obtain permission directly from the copyright holder. To view a copy of this licence, visit http://creativecommons. org/licenses/by/4.0/.

\section{References}

Aigbomian EP, Fan M (2013) Development of wood-crete from hardwood and softwood sawdust. Open Constr Build Technol J (7):108-117. https://benthamopen.com/contents/pdf/TOBCTJ/ TOBCTJ-7-108.pdf

Aladenola OO, Ajayi AE, Olufayo AA, Ajayi B (2008) Assessment of Gmelina arborea sawdust-cement-bonded rainwater storage tank. Environmentalist 28:123-127. https://doi.org/10.1007/ s10669-007-9119-3

Alm D, Karlsson G (2016) Waste wood for electricity productionpossible solutions for IKEA industry. Lund University. http:// 
lup.lub.lu.se/luur/download?func=downloadFile\&recordOId= $8892546 \&$ fileOId $=8892548$

Amiandamhen SO, Izekor DN (2013) Effect of wood particle geometry and pre-treatments on the strength and sorption properties of cement-bonded particle boards. J Appl Nat Sci $5(2): 318-322$

Amiandamhen SO, Izekor DN, Balogun AO (2016) Performance characteristics of treated kenaf bast fibre reinforced cement composite. J Indian Acad Wood Sci 13(2):156-160. https://doi. org/10.1007/s13196-016-0180-8

Ardanuy M, Claramunt J, Toledo FRD (2015) Cellulosic fiber reinforced cement-based composites: a review of recent research. Constr Build Mater. https://doi.org/10.1016/j.conbuild mat.2015.01.035

ASTM D1037 (2012) Standard test methods for evaluating properties of wood-base fiber and particle panel materials. https://doi.org/ $10.1520 / \mathrm{D} 1037-12.1$

Badejo SOO (1988) Effect of flake geometry on properties of cementbonded particleboard from mixed tropical hardwoods. Wood Sci Technol 22(4):357-369. https://doi.org/10.1007/BF00353325

Castro V, Parchen C, Iwakiri S, Castro V, Parchen C, Iwakiri S (2018) Particle sizes and wood/cement ratio effect on the production of vibro-compacted composites. Floresta e Ambiente 25(4). https:// doi.org/10.1590/2179-8087.021315

Effah B, Antwi K, Boampong E, Asamoah JN, Asibey O (2015) The management and disposal of small scale sawmills residues at the Sokoban and Ahwia wood markets in Kumasi-Ghana. Int J Innov Sci Res 19(1):15-23. http://www.ijisr.issr-journals.org/

BS EN 634-2 (2007) Cement-bonded particleboards-specifications-part 2: requirements for OPC bonded particleboards for use in dry, humid and external conditions. British Standard

Fabunmi OEB, Ibrahim FO, Jimoh SM, Idowu IO (2012) Management of sawmill wastes in Nigeria: case study of Minna, Niger State. Greener J Sci Eng Technol Res 3(4):127-134. www. gjournals.org

Fan M, Ndikontar MK, Zhou X, Ngamveng JN (2012) Cementbonded composites made from tropical woods: compatibility of wood and cement. Constr Build Mater 36:135-140. https://doi. org/10.1016/J.CONBUILDMAT.2012.04.089

Frybort S, Mauritz R, Teischinger A, Müller U (2008) Cement bonded composites - a mechanical review. BioResources 3(2):602-626

Garcez MR, Garcez EO, Machado AO, Gatto DA (2016) Cementwood composites: effects of wood species, particle treatments and mix proportion. Int J Compos Mater 6(1):1-8. https://doi. org/10.5923/j.cmaterials.20160601.01
Hachmi M, Guelzim M, Hakam A, Sesbou A (2017) Wood-cement inhibition revisited and development of new wood-cement inhibitory and compatibility indices based on twelve wood species. Holzforschung 71(12):991-998. https://doi.org/10.1515/ hf-2017-0022

Karade SR, Irle M, Maher K (2003) Assessment of wood-cement compatibility: a new approach. Holzforschung 57:672-680

Miljković J, Popović M, Điporović-Momčilović M, GavrilovićGrmuša I (2007) Edge screw withdrawal resistance in conventional particleboard and OSB-influence of the particles type. Гласник Шумарског Факултета 95:109-117. https://core.ac.uk/ download/pdf/27230523.pdf

Na B, Wang Z, Wang H, Lu X (2014) Wood-cement compatibility review. Wood Res 59(5):813-826. http://www.centrumdp.sk/wr/ 201405/20140510.pdf

Okino EY, de Souza MR, Santana MA, Alves MVS, de Sousa ME, de, Teixeira DE, (2004) Cement-bonded wood particleboard with a mixture of eucalypt and rubberwood. Cement Concr Compos 26(6):729-734. https://doi.org/10.1016/S09589465(03)00061-1

Owoyemi J, Ogunrinde O (2016) Accelerated aging assessment of cement bonded board produced from Gmelina arborea (Roxb.) strand and sawdust. Int J Sci Res Multidiscip Stud 2(7):1-6. www.isroset.org

Rammer DR, Zelinka SL (2004) Review of end grain nail withdrawal research. www.fpl.fs.fed.us

Savastano H, Coutts R, Warden P (2000) Brazilian waste fibres as reinforcement for cement-based composites. Cement Concr Compos 22(2000):379-384. https://www.academia.edu/ 7918630/Brazilian_waste_fibres_as_reinforcement_for_cementbased_composites

Semple KE, Cunningham RB, Evans PD (2002) The suitability of five Western Australian mallee eucalypt species for wood-cement composites. Ind Crops Prod 16(2):89-100. https://doi.org/10. 1016/S0926-6690(02)00012-2

Sotannde OA, Oluwadare AO, Ogedoh O, Adeogun PF (2012) Evaluation of cement-bonded particle board produced from Afzelia africana wood residues. J Eng Sci Technol 7(6):732-743

Tittelein P, Cloutier A, Bissonnette B (2012) Design of a low-density wood-cement particleboard for interior wall finish. Cement Concr Compos 34(2):218-222. https://doi.org/10.1016/j.cemcon comp.2011.09.020

Publisher's Note Springer Nature remains neutral with regard to jurisdictional claims in published maps and institutional affiliations. 